\title{
THE EFFICACY OF THE SYMPTOMATIC THERAPY OF THE NON-ATOPIC BRONCHIAL ASTHMA ATTACK IN SCHOOLCHILDREN
}

\section{S.I. Sazhyn}

Abstract. The effectiveness of symptomatic treatment of bronchial asthma in children has been studied. It has been found that patients with non-atopic asthma phenotype were characterized by more severe bronchial obstruction during exacerbations compared with atopic patients. Children afflicted with nonatopic phenotype of the disease were characterized by more pronounced signs of airway obstruction during the whole hospitalization period despite the identical standard regimens in the comparison groups.

Key words: bronchial asthma, children, symptomatic treatment, exacerbation.

Bukovinian State Medical University (Chernivtsi)

Рецензент - проф. Т.В. Сорокман

Buk. Med. Herald. - 2014. - Vol. 18, № 1 (69). - P. 91-95

Надійшла до редакції 13.11.2013 року

(C) C.I. Сажин, 2014

УДК 616.13-005.4-089.12:617.58

\section{P.В. Салютін}

\section{ЛІКУВАННЯ ХРОНІЧНОЇ ІШЕМЇ̈ НИЖНІХ КІНЦІВОК ІЗ ЗАСТОСУВАННЯМ МЕТОДУ КЛІТИННОЇ НЕПРЯМОЇ РЕВАСКУЛЯРИЗАЦЇ}

Координаційний центр трансплантації органів, тканин та клітин, м. Київ

\begin{abstract}
Резюме. Проблема лікування хворих із нереконструктабельним ураженням периферичного артеріального русла є актуальною та до кінця не вирішеною. Результати проведеного експериментального дослідження зі змодельованою ішемією кінцівки довели доцільність та ефективність застосування прогеніторних клітин фетальної печінки 3 метою активації регенераторновідновних процесів та ангіогенезу.

Метою наукової роботи було дослідження клінічної ефективності методу клітинної «непрямої» реваску-
\end{abstract}

Вступ. Враховуючи велику кількість випадків захворювання на хронічну ішемію нижніх кінцівок, що зумовлює високий відсоток летальності та інвалідизації пацієнтів, особливо старшого віку, необхідний пошук нових методів лікування цієї хвороби. В умовах ураження дистального артеріального русла та мікроангіопатії, якщо виконана раніше «пряма» реваскуляризація визнана неефективною або відсутні покази до іiі виконання, важливого значення набувають методи «непрямої» реваскуляризації $[1,4]$.

Одним із напрямів сучасних досліджень $€$ використання клітинних технологій $з$ метою активації процесів ангіогенезу на рівні колатеральної артеріальної сітки, зокрема за допомогою уведення стромальних автологічних стовбурових клітин кісткового мозку та жирової тканини [3, 6]. Однак широке клінічне використання клітин кісткового мозку та жирової тканини обмежено певними технологічними проблемами та низьким ляризації в комплексному лікуванні хворих на хронічну ішемію нижніх кінцівок.

Розроблена методика застосування прогеніторних клітин фетальної печінки людини в комплексному лікуванні ішемії нижніх кінцівок $\epsilon$ ефективним і доступним методом «непрямої» реваскуляризації. Цей метод показаний до використання у пацієнтів, яким неможливо виконати реконструкцію судинного русла, в осіб літнього віку та з вираженою супутньою патологією.

Ключові слова: хронічна ішемія, непряма реваскуляризація, прогеніторні клітини, фетальна печінка.

потенціалом трансдеференціювання дорослих (abult) мезенхімальних клітин [5]. Прогеніторні клітини фетальної печінки людини 6-8 тижнів гестації експресують CD 34+, CD 38-, CD 45Ra ${ }^{\text {low }}$, $\mathrm{CD} 71^{\text {low }}$, що свідчить про високий потенціал трансдиференціювання до ангіобластів та ендотеліоцитів - основної складової капіляра, зумовлюючи значну потенцію до стимуляції процесів ангіогенезу, ніж автоклітини кісткового мозку або жирової тканини [2], та має підтвердження результатами експериментального дослідження, проведеного на щурах.

Таким чином, застосування «непрямої» клітинної реваскуляризації з використанням клітинних культур фетального походження, 3 метою стимуляції ангіогенезу за умов ішемії, має теоретичне та експериментальне підгрунтя та $є$ досить перспективним напрямком науково-практичних розробок. 
Мета дослідження. Дослідити клінічну ефективність методу клітинної «непрямої» реваскуляризації в комплексному лікуванні хворих на хронічну ішемію нижніх кінцівок.

Матеріал і методи. Розроблена оригінальна методика «непрямої» реваскуляризації з використанням прогеніторних стовбурових клітин фетальної печінки людини, у хворих на хронічну ішемію кінцівок, складається 3 двох етапів: 1-й - ретельне обстеження та наявність показів до «непрямої» клітинної реваскуляризації; 2-й - найбільш оптимально поєднане (локальне+системне) уведення раніш заготовлених прогеніторних клітин фетальної печінки.

Методика застосована у 21 пацієнта (всі чоловіки) з проявами хронічної ішемії нижніх кінцівок, хворих на облітеруючий ендартеріїт (4 пацієнти), облітеруючий атеросклероз (17), які перебували на лікуванні у відділі мікросудинної та пластичної хірургії Національного інституту хірургії та трансплантології ім. О.О. Шалімова та клініці ТОВ «Інститут клітинної терапії». Середній вік пацієнтів складав 53,5 року. Обстеження осіб до операції включало допплерографію артерій, рентгенконтрастну ангіографію, лазерну флуометрію мікроциркуляторного русла. У всіх пацієнтів констатовано неможливість виконання реконструктивно-відновних оперативних втручань на артеріальному руслі нижньої кінцівки.

Прогеніторні клітини фетальної печінки людини 6-8 тижнів гестації з фенотипом CD $34^{+}, \mathrm{CD}$ 38, $\mathrm{CD} 45 \mathrm{Ra}^{\text {low }}, \mathrm{CD} 71^{\text {low }}$ (кількість КУО-ГМ $140.0 \times 10^{3}$ мл), отримували згідно 3 договором iз біотехнологічної лабораторії ТОВ «Інститут клітинної терапії». Клітинний аспірат уводили внутрішньом'язово в кінцівку (сегмент гомілкастопа), у вигляді доріжки вздовж оклюзійних артерій, додатково поєднуючи із системним (внутрішньовенно) уведенням.

Індекс якості життя визначали за методом W.O. Spitzer. Опитальником із визначення дистанції ходьби був Walking Impairment Questionnaire.

Гістологічний та імуногістохімічний аналіз біопсійного матеріалу виконували перед та через три і шість місяців після операції, на базі лабораторії патоморфології Інституту педіатрії, акушерства та гінекології НАМН України.

Результати дослідження та їх обговорення. За результатами клінічного дослідження, у $88,2 \%$ пацієнтів через $1-3$ місяці після «непрямої» клітинної реваскуляризації спостерігали зменшення ступеня ішемії за методом Покровського - Фонтейна. Чотири пацієнти 3 IV ступенем перейшли до III ступеня, а в чотирьох пацієнтів характер клінічних проявів через три місяці після операції відповідав II А ступені ішемії (табл.).

Водночас у двох хворих з IV ступенем ішемії 3 гнійно-запальним процесом на стопі (гангрена пальців із переходом на тильну поверхню стопи) позитивної клінічної динаміки не спостерігали. Навпаки, уведення прогеніторних клітин фетальної печінки людини призвело до стимуляції гнійно-запального процесу, пожвавленню некротичного процесу та активації латентної мікотичної інфекції, що в кінцевому підсумку змусило виконати ампутацію кінцівки (на рівні гомілки та стегна).

Окрім того, одному пацієнту з периферичною формою ураження ампутація кінцівки виконана через чотири місяці після клітинної «непрямої» реваскуляризаіі. На тлі повного благополуччя та переходу ступеня ішемії з III на II А зафіксували гострий артеріальний тромбоз підколінної артерії 3 переходом до Гунтерова каналу.

При проведенні клінічного дослідження 3 метою оцінки ефективності застосування клітинної «непрямої» реваскуляризації, у комплексному лікуванні хворих на хронічну ішемію кінцівок, використано визначення індексу якості життя та дистанції ходьби.

Індекс якості життя в дослідній групі пацієнтів до лікування складав 4,12 $\pm 0,13$ бала, що відповідає середньому показнику в осіб, яким проводилася консервативна терапія і свідчить про однорідність порівнювальних груп. Однак вже на третій місяць після уведення клітинного аспірату вищенаведений показник перевищував індекс життя хворих, яким проводили курс консервативної терапії в 1,12 раза, а на 12-й міс. індекс якості життя перевищував аналогічний показник контрольної групи в 1,5 раза.

Дистанція без больової ходьби та швидкість руху в пацієнтів дослідної групи також поступово зростала, відрізняючись від аналогічного показника контрольної групи на 6-й міс. спостереження в 1,1 раза, а на 12-й міс. - в 1,4 раза (складаючи 29,5 $\pm 1,02$ бала).

Таким чином, на підставі використання опитувальників можливо оцінити якість життя паціє-

Таблиця

Динаміка ступеня ішемії кінцівки в післяопераційному періоді

\begin{tabular}{|c|c|c|}
\hline $\begin{array}{c}\text { Ступінь хронічної ішемії } \\
\text { (за Покровським - Фонтейном) }\end{array}$ & $\begin{array}{c}\text { Кількість хворих до клітинної } \\
\text { «непрямої» реваскуляризації }\end{array}$ & $\begin{array}{c}\text { Кількість хворих, 6 місяців після } \\
\text { уведення клітин }\end{array}$ \\
\hline I & - & - \\
\hline II А & - & $4(+4)$ \\
\hline II Б & 7 & $9(+2)$ \\
\hline III & 8 & $5(+4)$ \\
\hline IV & 6 & $(-3)$ \\
\hline Всього & 21 & 18 \\
\hline
\end{tabular}


нта 3 хронічною ішемією кінцівок на різні терміни лікування. Однак зауважимо що оцінка якості життя та відстані ходьби не завжди є адекватними щодо оцінки ефективності лікування, оскільки не відображають зміни об'єктивних клінічних характеристик у післяопераційному періоді.

Результати рентгеноконтрастної артеріографії в доопераційному періоді вказували на наявність облітеруючого або оклюзійного ураження магістрального судинного русла кінцівки, його локалізацію та розповсюдженість і наявність колатерального кровотоку по судинах великого та середнього калібру. На контрольній артеріографії через 6-12 місяців після клітинної «непрямої» реваскуляризації спостерігали збільшення колатеральної судинної мережі у вигляді розгалужених судин великого та середнього калібру, які локалізувалися вздовж облітерованих магістральних артерій та анастомозували з їх фрагментами, в яких мале місце залишкове кровонаповнення.

У хворих на хронічну ішемію кінцівок, на тлі зниження рівня мікроциркуляції, компенсаторно активізувалися механізми мікроциркуляторної регуляції (ендотеліальні, нейрогенні, міогенні), посилювалося артеріовенозне шунтування, знижувалися ендотелій-залежний i ендотелійнезалежний резерви капілярного кровотоку.

Проте вже наприкінці першого місяця після клітинної «непрямої» реваскуляризації засвідчено покращання мікроциркуляторних показників. Та упродовж року після операції відмічено стійку тенденцію до подальшої нормалізації стану мікроциркуляторного русла за рахунок функціонування новоутвореного капілярного русла, дилатації прекапілярних сфінктерів (за рахунок зниження нейротонусу), зменшення патологічного артеріовенозного шунтування та збільшення резерву капілярного кровотоку (за рахунок поліпшення ендотелій - незалежної вазодилатації). Однак після 12 місяців із часу операції, показники процесів мікроциркуляції мають тенденцію до «завмирання» та формування стійкого позитивного рівня капілярного кровотоку.

Результати гістологічного та імуногістохімічного дослідження біоптатів м'язової тканини на 12-й місяць після «непрямої» клітинної реваскуляризації свідчили про стабілізацію регенераторно-відновних процесів та васкулоангіогенезу.

\section{Висновки}

1. Застосування методу клітинної «непрямої» реваскуляризації з використанням прогеніторних клітин фетальної печінки людини є ефективним у комплексному лікуванні хворих на хронічну ішемію кінцівок.

2. Найбільш оптимальним шляхом уведення прогеніторних клітин фетальної печінки людини $\epsilon$ локальна трансплантація в ішемізовану кінцівку (під місцевою анестезією шприцом 3 короткою канюлею), поєднана із системним (внутрішньовенним) уведенням клітин.

3. Використання методу клітинної «непрямої» реваскуляризації призводить до підвищення індексу якості життя, а також до стійкого зростання дистанції та швидкості ходьби, що суттєво відрізняється від аналогічних показників пацієнтів, що отримали курс консервативного лікування.

4. За даними інструментальних досліджень доведено, що завдяки уведенню прогеніторних клітин фетальної печінки людини відбувається активація регенераторно-відновних процесів та васкуло-ангіогенезу, зменшуються прояви ішемічного синдрому та покращується клінічний стан хворого.

1. Русин В.І. Хірургічне лікування дистальних форм атеросклеротичного ураження артерій нижніх кінцівок / В.I. Русин, В.В. Корсак, Я.М. Попович // Практ. мед. - 2008. - Т. 14, № 5. - С. 210-213.

2. Григорян А.С. Выделение мультипотентных прогениторных клеток из фетальной печени человека / А.С. Григорян // Клет. трансплантол. и ткан. инженерия. -2007 - Т. I, № 4. - С. 18-19.

3. Косенков А.Н. Хроническая критическая ишемия нижних конечностей и сахарный диабет у лиц пожилого и старческого возраста / А.Н. Косенков, А.И. Черепанин, С.В. Удовиченко // Клин. геронтол. 2007. - № 5. - С. 34-38.

4. Выбор метода реконструктивной операции при дистальной окклюзии артерий нижних конечностей / А.С. Никоненко, А.В. Губка, В.И. Перцов [и др.] // Клін. хірургія. - 2005. - № 4-5. - С. 57-59.

5. Structural and functional remodeling of skeletal muscle microvasculature is induced by simulated microgravity / M.D. Delp, P.N. Colleran, M.K. Wilkerson [et al.] // Am. J. Physiol. Heart. Circ. Physiol. - 2005. - Vol. 5, № 4. P. 278-299.

6. Lachmann N. Therapeutic angiogenesis for peripheral artery disease: stem cell therapy / N. Lachmann, S. Nikol // Vasa. - 2007. - Vol. 36, № 4. - P. 241-251.

\section{ЛЕЧЕНИЕ ХРОНИЧЕСКОЙ ИШЕМИИ НИЖНИХ КОНЕЧНОСТЕЙ С ИСПОЛЬЗОВАНИЕМ МЕТОДА КЛЕТОЧНОЙ НЕПРЯМОЙ РЕВАСКУЛЯРИЗАЦИИ}

\section{Р.В. Салютин}

Резюме. Проблема лечения больных с нереконструктабельным поражением периферического артериального русла является актуальной и до конца нерешенной. Результаты проведенного экспериментального исследования со смоделированной ишемией конечности доказали целесообразность и эффективность применения прогениторных клеток фетальной печени с целью активации регенерационно-восстановительных процессов и ангиогенеза.

Целью научной работы было исследование клинической эффективности метода клеточной «непрямой» реваскуляризации в комплексном лечении больных хронической ишемией нижних конечностей. 
Разработанная методика применения прогениторных клеток фетальной печени человека в комплексном лечении ишемии нижних конечностей является эффективным и доступным методом непрямой реваскуляризации. Этот метод показан к использованию у пациентов, которым невозможно выполнить реконструкцию сосудистого русла, больных преклонного возраста и с выраженной сопутствующей патологией. чень.

Ключевые слова: хроническая ишемия, косвенная реваскуляризация, прогениторные клетки, фетальная пе-

\title{
USING CELL INDIRECT REVASCULARIZATION FOR CHRONIC LIMB ISHEMIA
}

\section{R.V. Saliutin}

Abstract. The problem of treating patients with no reconstruction of peripheral arterial bed is relevant and it still remans open. The results of the pilot study with a simulated limb ischemia, demonstrated the feasibility and efficacy of fetal liver progenitor cells in activating regenerative and recovery processes as well as angiogenesis.

The aim of the research was to investigate the clinical efficacy of cell "indirect" revascularization method in the complrehensive treatment of patients with chronic limb ischemia.

The developed method of fetal human liver progenitor cells application in treatment of lower limb ischemia is an effective and affordable method of indirect revascularization. This method is indicated for use in patients whose vascular bed can not be reconstructed, and in elderly patients with severe concomitant pathologies.

Key words: chronic ischemia, indirect revascularization, progenitor cells, fetal liver.

Coordination center of organs, tissues and cell transplantation (Kyiv)

Рецензент - д. мед. н. Д.Б. Домбровський

Buk. Med. Herald. - 2014. - Vol. 18, № 1 (69). - P. 95-98

Надійшла до редакції 04.12.2013 року

(C) Р.В. Салютін, 2014

УДК 616-078:616.12-007.61+[612.17+616.122]:616.12-008.46:616.127-005.8:616.12-008.331.1

\author{
В.Д. Сиволап, Я.В. Земляний
}

\section{РІВНІ РОСТОВОГО ФАКТОРУ ДИФЕРЕНЦІЮВАННЯ 15, N-КІНЦЕВОГО ФРАГМЕНТУ МОЗКОВОГО НАТРІЙУРЕТИЧНОГО ПЕПТИДУ ТА СТРУКТУРНО-ФУНКЦІОНАЛЬНИЙ СТАН СЕРЦЯ У ХВОРИХ НА СЕРЦЕВУ НЕДОСТАТНІСТЬ ЗІ ЗБЕРЕЖЕНОЮ ФРАКЦІЕЮ ВИКИДУ, ЯКІ ПЕРЕНЕСЛИ ІНФАРКТ МІОКАРДА НА ТЛІ АРТЕРІАЛЬНОЇ ГІПЕРТЕНЗЇ̈}

Запорізький державний медичний університет

Резюме. У 69 хворих на серцеву недостатність 3 постінфарктним кардіосклерозом та збереженою фракцією викиду лівого шлуночка (ФВ $>45 \%)$ були досліджені рівні ростового фактору диференціювання 15 (GDF-15), N-кінцевого фрагменту мозкового натрійуретичного пептиду (NTproBNP) та структурно-функціональні зміни серця. Виявлено, що у хворих на серцеву недостатність зі збереженою фракцією викиду, які перенесли інфаркт міокарда на тлі артеріальної гіпертен- зії, спостерігається підвищення рівнів GDF 15 та NTproBNP. Виявлена кореляція цих біомаркерів із показниками діастолічної дисфункції лівого шлуночка та індексом об'єму лівого передсердя.

Ключові слова: серцева недостатність, інфаркт міокарда, ростовий фактор диференціювання $15, \mathrm{~N}$ кінцевий фрагмент мозкового натрійуретичного пептиду.

Сьогодні для ранньої діагностики та прогнозування перебігу ХCH використовуються окремі біомаркери. Найбільш обгрунтованими 3 них $\epsilon$ дослідження мозкового натрійуретичного пептиду та його метаболітів, зокрема NTproBNP [7]. До перспективних біомаркерів серцевої недостатності відносять визначення ростового фактору диференціювання 15 (GDF-15) [6, 10, 11]. Існують дані, що GDF 15 є більш точним маркером CНЗФB, у той час як NTproBNP краще відображає перебіг систолічної СН [10]. 